\title{
Cardioneuroablation: Catheter Vagal Denervation as a New Therapy for Cardioinhibitory Syncope
}

\author{
Cardioneuroablação: A Denervação Vagal por Cateter Como Nova Terapia \\ para Síncope Cardioinibitória
}

José Carlos Pachón Mateos ${ }^{1,2,3,{ }^{*}}$, Enrique Indalécio Pachón Mateo ${ }^{1,2}$, Christian Higuti 1,2, Tasso Júlio Lobo², Tomas Guillermo Santillana Peña², Carlos Thiene Cunha Pachón², Juan Carlos Pachón Mateos $^{1,2,3}$, Juán Carlos Zerpa Acosta², Felipe Ortencio², Ricardo Amarante ${ }^{1,2}$.

ORCID IDS

Mateos JCP (D) https://orcid.org/0000-0002-5111-488X

Mateos EIP (D) https://orcid.org/0000-0001-7509-0731

Higuti C (D) https://orcid.org/0000-0003-3820-8600

Lobo TJ (D) https://orcid.org/0000-0002-2801-1903

Peña TGS (D) https://orcid.org/0000-0001-5795-9827

\author{
Pachón CTC (DD_https://orcid.org/0000-0003-3943-4722 \\ Mateos JCP (D) https://orcid.org/0000-0003-4410-8753 \\ Acosta JCZ (D) https://orcid.org/0000-0001-7436-2299 \\ Ortencio F (D) https://orcid.org/0000-0003-1805-0420 \\ Amarante R (D) https://orcid.org/0000-0002-7181-8198
}

\begin{abstract}
The vasovagal syncope is the most frequent cause of transient loss of consciousness, especially in young people without significant heart disease. Malignant cardioinhibitory form is caused by abrupt and intense vagal reflex with or without defined triggers. Refractory cases to preventive measures and pharmacological handling, has been treated with definitive pacemaker implantation. Besides showing questionable results, pacemaker implantation is highly rejected by young patients. In the late 1990s, we proposed a specific vagal denervation by catheter ablation and spectral mapping, for paroxysmal AF, functional bradyarrhythmias and severe cases of malignant cardioinhibitory syncope giving rise to cardioneuroablation. Recently, many authors worldwide have been reproducing the cardioneuroablation results where elimination or significant reduction of the vagal response were observed, which abolished symptoms in more than $75 \%$ of patients followed up to 14 years, without complications. Therefore, cardioneuroablation has shown to be a real therapeutic option in malignant syncope cardioinhibitory and in any exclusive vagal mediated bradyarrhythmia without the need of pacemaker implantation.
\end{abstract}

KEYWORDS: Vasovagal Syncope; Malignant Neurocardiogenic Syncope; Catheter Ablation; Vagus Nerve Stimulation.

\begin{abstract}
RESUMO
A síncope vasovagal é a causa mais frequente de perda transitória de consciência, especialmente em jovens sem doença cardíaca significativa. A forma cardioinibitória maligna é causada por reflexo vagal abrupto e intenso com ou sem gatilhos definidos. Casos refratários a medidas preventivas e manuseio farmacológico foram tratados com implante definitivo de marcapasso. Além de apresentar resultados questionáveis, o implante de marcapasso é altamente rejeitado por pacientes jovens. No final dos anos 1990, propusemos uma denervação vagal específica por ablação do cateter e mapeamento espectral para FA paroxística, bradiarritmias funcionais e casos graves de síncope cardioinibitória maligna dando origem à cardioneuroablação. Recentemente, muitos autores em todo o mundo vêm reproduzindo os resultados da cardioneuroablação, onde se observou eliminação ou redução significativa da resposta vagal, o que aboliu sintomas em mais de $75 \%$ dos pacientes acompanhados por até 14 anos, sem complicações. Portanto a cardioneuroablação tem se mostrado uma verdadeira opção terapêutica na síncope cardioinibitória maligna e em qualquer bradiarritmia vagal exclusiva mediada sem a necessidade de implante de marcapasso.
\end{abstract}

PALAVRAS-CHAVE: Síncope Vasovagal; Síncope Neurocardiogênica; Ablação por cateter; Estimulação do Nervo Vago.

1.Universidade de São Paulo - São Paulo (SP) - Brazil.

2. Hospital do Coração - Serviço de Eletrofisiologia, Marcapasso e Arritmias - São Paulo (SP) - Brazil.

3.Instituto Dante Pazzanese de Cardiologia - Serviço de Marcapasso - São Paulo (SP) - Brazil.

*Correspondence author: pachon@usp.br

Received: 08 Nov 2019 | Accepted: 19 Nov 2019

Section Editor: J. Tarcísio Medeiros de Vasconcelos 


\section{INTRODUCTION}

According to the 2015 Heart Rhythm Society Expert Consensus, syncope is defined as a transient loss of consciousness, associated with an inability to maintain postural tone, rapid and spontaneous recovery, and the absence of clinical features specific for another form of transient loss of consciousness such as epileptic seizure $^{1}$. Common causes of syncope are the vasovagal, orthostatic hypotension, and cardiac disorders. The vasovagal syncope, neurocardiogenic or reflex syncope is the most frequent, especially in the younger population with no apparent heart disease ${ }^{1}$. It is a very frequent clinical problem that reduces the quality of life and may increase the risk of trauma. Usually, it is a transient loss of consciousness due to a reflex response, caused by intense bradycardia or asystole (cardioinhibitory type) associated to a greater or lesser vasodepression degree (mixed type). Infrequently, the vasovagal syncope is caused by lone vasodepression (vasodepressor type).

Despite controversial results and some degree of uncertainty, pacemaker has been considered the treatment of choice for severe cardioinhibitory syncope without response to clinical treatment ${ }^{1,2}$. However, besides showing a questionable result, the pacemaker is associated with great rejection by these patients, usually young and without apparent heart disease. As the cardioinhibitory response is mediated by a huge vagal reflex, the first proposal for autonomic ablation, more specifically vagal denervation by using RF catheter ablation in atrial walls (Cardioneuroablation - CNA) was published in 2005, as a definitive treatment for the severe cardioinhibitory syncope, being the first patient ablated in $2002^{1}$. The great advantage of this method was the possibility of treatment without pacemaker implantation.

\section{Vasovagal syncope}

Also known as reflex, neurocardiogenic or vasovagal syncope, it is caused by a reflex mechanism, through multiple triggers, ending with intense cardioinhibition and/or vasodilatation leading to severe and transient hypotension. The cardioinhibition can be enough to cause prolonged asystole. Typically, the patient recovers spontaneously within minutes. Depending on the physiopathology, it can be classified as cardioinhibitory, vasodepressor or mixed. The first is characterized by asystole, severe bradycardia and/or transient total AV block caused by intense vagal action. In the vasodepressor form, severe hypotension without significant bradycardia usually occurs, mainly due to a sudden reduction in sympathetic tone ${ }^{2}$. In the mixed form, there is the contribution more or less intense of the two mechanisms.

\section{CARDIAC AUTONOMIC NERVOUS SYSTEM}

\section{Anatomy}

The autonomic nervous system of the heart consists of three major divisions, one afferent - the sensory nervous system - and two efferent partitions, the parasympathetic and sympathetic branches. The medulla oblongata is the main center for integration of cardiac innervation whose activity is modulated by the hypothalamus and more superior centers. The sensory fibers are bipolar neurons whose cells bodies are in the medulla oblongata. The efferent fibers comprise essentially two main neurons, the pre and the post-postganglionic. The parasympathetic postganglionic fiber is very short because its body neuron is located in the heart, mainly in the atrial wall and in the ganglionated plexuses (paracardiac fat pads) ${ }^{3}$. The cell body of the parasympathetic preganglionic neuron placed is in the medulla oblongata, more specifically in the nucleus ambiguous and in the vagus dorsal motor nucleus ${ }^{4}$. Its axon is led to the heart by the vagus nerves. In contrast, the sympathetic postganglionic neuron is too long because their cell body is sited in the paravertebral sympathetic chain. The result of this distribution is that only the parasympathetic postganglionic body neuron is located in the heart and only this one is prone to be eliminated by the endocardial RF ablation.

\section{Physiology}

Despite being the heart a striated muscle, its activity does not depend on the innervation. Unlike the skeletal muscle that atrophies when denervated, the heart retains its normal metabolism, structure and activity independent on the innervation. This fact is easily observed in cardiac transplantation patients. However, the autonomic nervous system acts permanently modulating all cardiac properties, through an intense inhibitory 
(parasympathetic) and excitatory (sympathetic) tone. This functional antagonism creates a balance mediated by the brain stem that determines the instantaneous heart rate. This balance is constantly restored by the autonomic nervous system by adjusting the cardiac physiology at every moment. Thereby, in the case of vagal denervation, a proportional reduction in the sympathetic tone determined by the reflex balance of the autonomic nervous system is usually observed, bringing down the cardiac rate back to baseline.

\section{Rationale}

The cardioinhibition of the reflex syncope is caused by a massive sudden vagal reflex that may be totally eliminated by vagal denervation. That is also elegantly proved by preventing the cardioinhibitory syncope by atropine ${ }^{5}$. Aiming a new definitive treatment for this condition, in the late nineties, we proposed a specific vagal denervation ${ }^{5}$, by endocardial ablation guided by spectral mapping, for treating paroxysmal $\mathrm{AF}$, functional bradyarrhythmias and severe cardioinhibitory syncope, given rise to cardioneuroablation. Since then, we have been studying the possibility of abolishing or attenuating, permanently, the cardioinhibitory reflex by using RF endocardial ablation. Although a temporary denervation can be obtained with the elimination of neural fibers, long-term denervation needs the elimination of cells bodies of the neurons to prevent reinnervation. As previously mentioned, cardiac innervation is composed of parasympathetic, sympathetic and sensory systems (Fig. 1). Only the parasympathetic innervation contains most of the postganglionic neuron within the heart, more specifically inside the atrial wall, on the epicardium, in the endocardium or in the paracardiac ganglia (epicardial fat pads). In contrast, the cells bodies of postganglionic sympathetic and sensory neurons lie, respectively, in the paravertebral chain ganglia and in the central nervous system, away from the heart. These features favor more selective vagal denervation since the cell body of the postganglionic parasympathetic neuron is the only directly exposed to RF application in atrial walls. The sympathetic and sensory body neurons are preserved and their function is usually recovered because only fibers endings are temporarily eliminated by endocardial RF energy ${ }^{6,7}$.

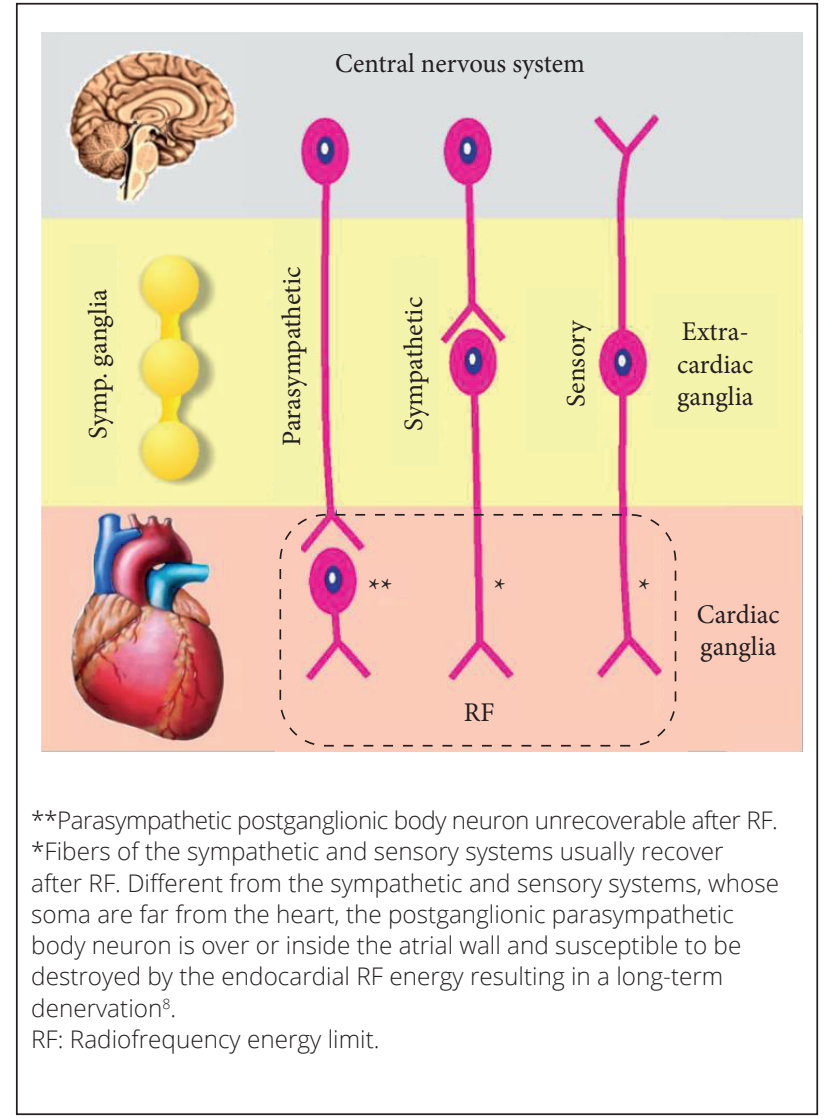

Figure 1. Sketch of the cardiac nervous system with the three main cardiac innervation partitions and the endocardial RF effect.

\section{CARDIAC AUTONOMIC DENERVATION}

Several attempts of cardiac denervation with purposes other than cardioinhibition treatment have been developed. Left stellectomy for the treatment of the Long QT Syndrome is a successful example by partially ablating the cardiac sympathetic nervous system ${ }^{9}$. More recently, surgical ablation of the epicardial ganglionated plexuses aiming treatment of atrial fibrillation has been tried $^{10,11}$. Unfortunately, this kind of denervation has not shown positive results ${ }^{12}$. In contrast, the vagal denervation to treat vasovagal syncope appears to be highly efficient. The first study proposing this kind of denervation by endocardial ablation to eliminate cardioinhibition caused by vagal reflex was published in $2005^{5}$, and the first patient was treated in 2002. Since then, significant advances were obtained and many distinguished authors have been able to reproduce the results ${ }^{13-21}$. 


\section{RF catheter ablation for vagal denervation}

The main purpose of the procedure is mapping and ablation of the vagal endings in the atrial wall. As the parasympathetic postganglionic neuron is sited inside or over the atrial wall and in the cardiac ganglionated plexuses, there is a great chance of getting their elimination by endocardial conventional RF. Nevertheless, the main challenge is the detection and mapping of endocardial innervation highdensity areas in order to release the RF. The hypothesis was that endocardial RF could be able to eliminate the existing postganglionic parasympathetic neuron in the atrial wall (first neuron, Fig. 2), in the visceral epicardium and even part of neurons located in the ganglionated plexuses (second neuron, Fig. 2). The purpose was to obtain enough denervation to eliminate or attenuate the vagal tone and the cardioinhibition in long term, making the vasovagal cardioinhibitory reflex more resistant to triggers.

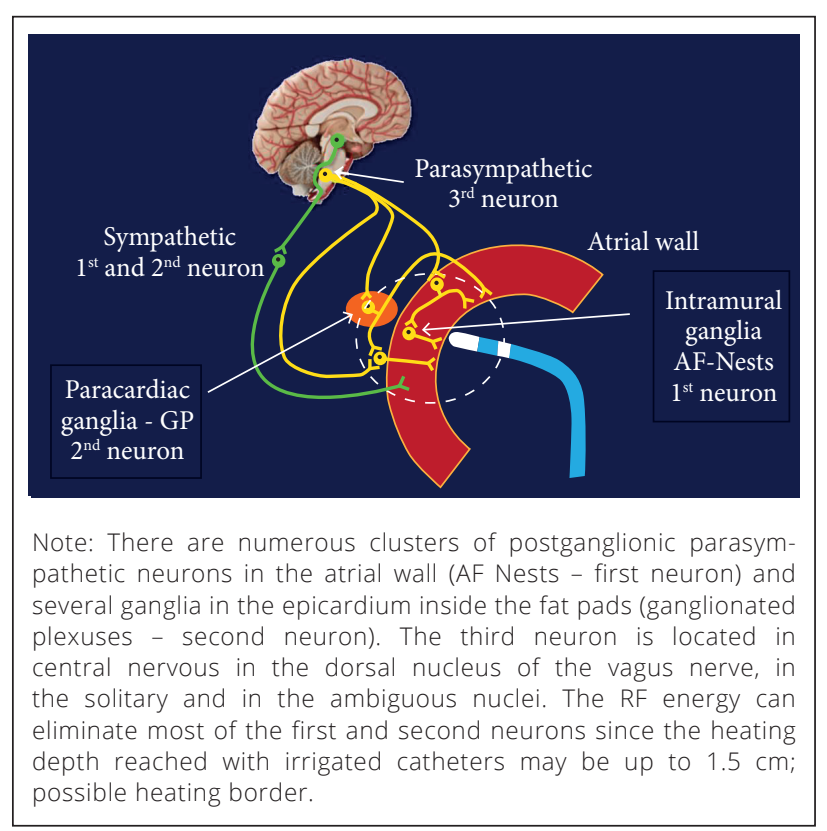

Figure 2. Scheme of the cardiac innervation and cardioneuroablation.

\section{Mapping and ablating the cardiac innervation by endocardial approach}

Unlike the skeletal muscle, the myocardium does not have a differentiate neuromuscular junction. In contrast, the nerve parasympathetic and sympathetic fibers directly penetrate the myocardium and interweave with the myocytes. Additionally, lots of microneurons (parasympathetic postganglionic neurons, first neuron in Fig. 2) colonize the atrial walls
(Figs. 4 and 5). This blend of cells changes some electrical properties of the atrial wall and may be identified by changes in the spectrum as "AF Nests"2-25 (this name resulted from its relation with the AF physiopathology as they present electrical resonance ${ }^{26,27}$ favoring the AF maintenance). Therefore, by using the spectral study during sinus rhythm, we have found two types of myocardium. The first one, the compact myocardium, is characterized by high amplitude, isotropic conduction and a smooth spectrum (Fig. 3a), whereas the second one, the fibrillar myocardium, has a low amplitude, anisotropic conduction and a segmented spectrum (Fig. 3b) $)^{26,28,31}$.

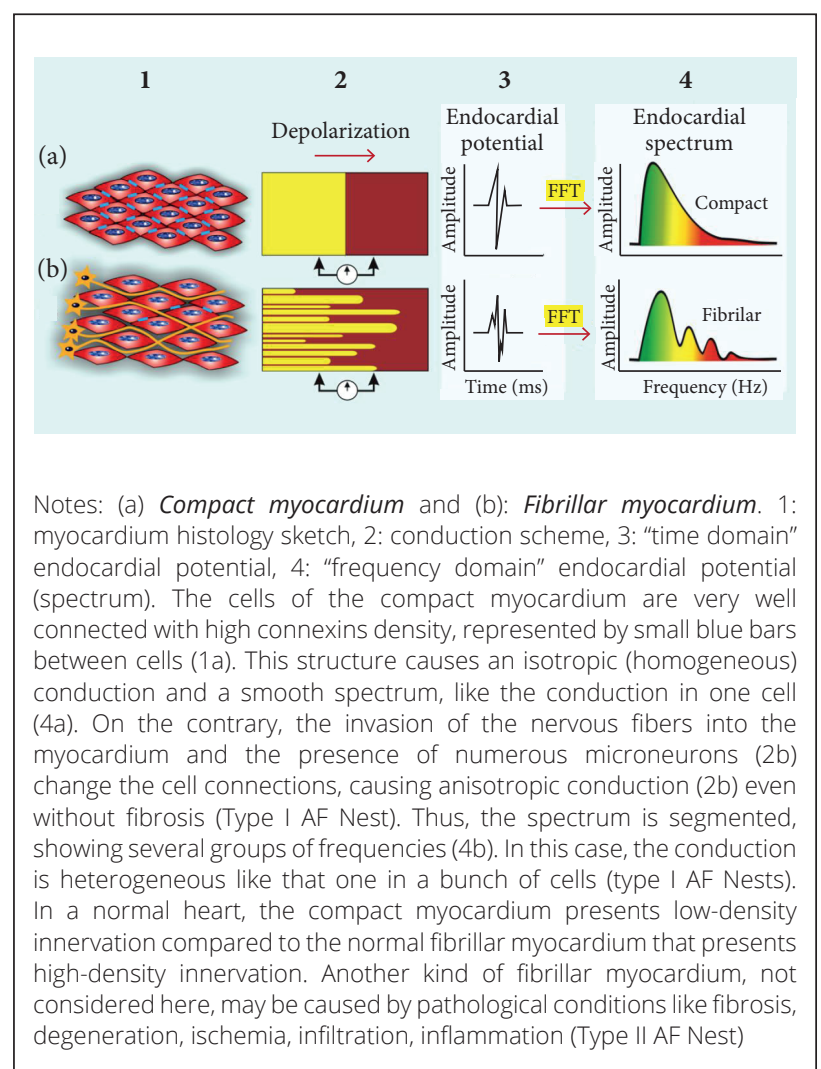

Figure 3. Differences in electrical properties of the myocardium depending on the connection grade of the cells.

Clusters of fibrillar myocardium give rise to AF Nests. Several findings have demonstrated a close relation between the fibrillar myocardium and the cardiac innervation interface:

- $\quad$ RF delivery in the septal fibrillar myocardium usually causes immediate autonomic reactions, such as a significant heart rate and Wenckebach's point increases $^{29,30,8}$; 
- Detailed studies based on neural staining have shown a high number of parasympathetic neurons and ganglia in the fibrillar myocardium areas ${ }^{31-33}$;

- A large amount of fibrillar myocardium is found in the anatomical regions of the cardiac ganglionated plexuses ${ }^{26,27,31}$.

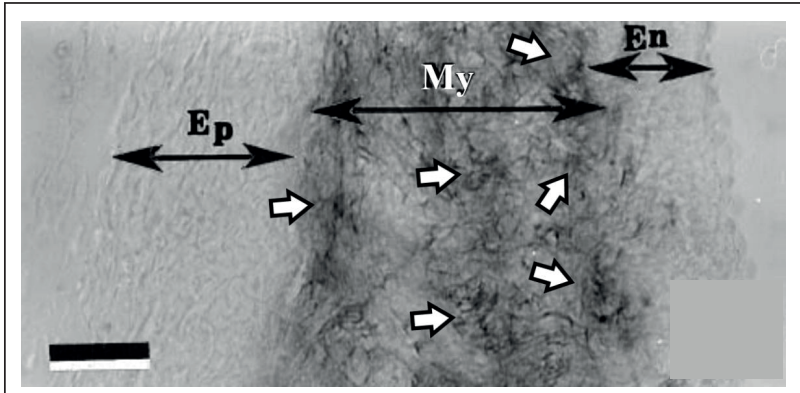

Ep: epicardium; My: myocardium; En: endocardium. Dark zones on photographs are myocardium stained for acetylcholinesterase. The white arrows indicate neuronal fibers and clusters of the first neuron in the atrial myocardium (AF-Nests). Scale bar $5100 \mu \mathrm{m}$. With permission of Pauza et $\mathrm{l}^{34}$.

Figure 4. Photomicrographs of cross-sections through an adult canine right atrial wall.

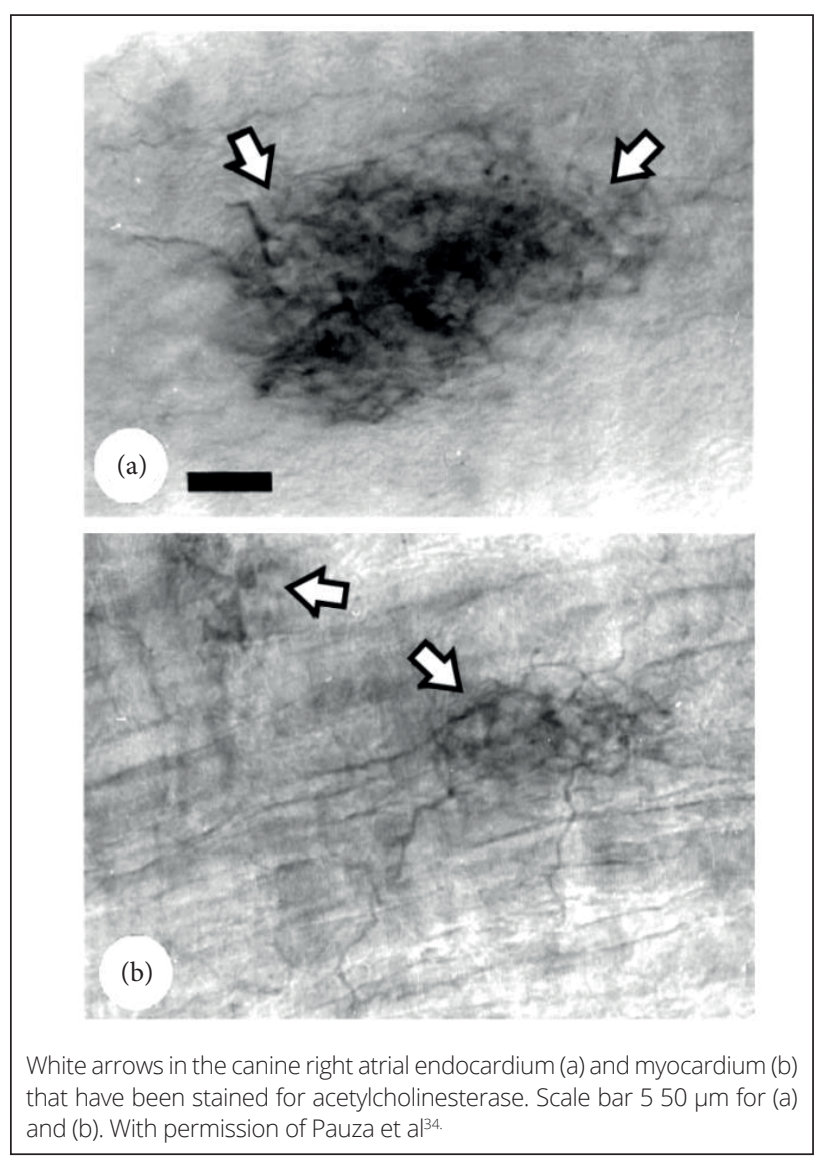

Figure 5. Examples of clusters of the first neuron in the atrial wall (AF Nests).

Through the on-line real-time spectral mapping, it is possible to disclose the fibrillar myocardium (AF Nests) to guide the ablation (Fig. 3Bb4) of the first neuron. Consequently, most of the postganglionic parasympathetic neurons may be abolished and do not recover, whereas the sympathetic and sensory terminal fibers usually recover from weeks to months (Fig, 2). Preganglionic vagal fibers may provide some grade of reinnervation but it is reduced as they have lost the postganglionic link replaced by some post-RF fibrosis.

\section{CARDIONEUROABLATION METHOD Inclusion criteria}

The success of the procedure depends on a strict inclusion criterion. The main one is the presence of a reflex and / or functional bradyarrhythmia in a symptomatic patient, without response or without the possibility of clinical treatment ${ }^{35}$ in an apparently normal heart or having rationally excluded a significant cardiopathy ${ }^{36}$. Likewise, pharmacological test to confirm the reversibility of the condition, as a positive response to the atropine, are decisive, Table 1.

Table 1. Cardioneuroablation inclusion criteria. During the atropine test, the heart rate must twofold or must reach more than $100 \mathrm{bpm}$ at least by $15 \mathrm{~min}$.

Reflex or functional symptomatic bradyarrhythmia

- Severe cardioinhibitory syncope

- Severe vasovagal syncope with a very important

- Cardioinhibitory component

- Symptomatic sinus node dysfunction or Brady-Tachy

syndrome

- Symptomatic functional AV block

Absence of significant cardiopathy

Normal response to atropine

(0.04 mg/kg = 2 $\times$ HR or HR > 100 bpm/15')

Impossibility or nonresponse to clinical treatment

\section{Method}

Since the patient has signed the consent form, the procedure is performed under general anesthesia. An important concern is that, inadvertently, the anesthesiologist may use atropine at the beginning of the procedure and that would make cardiologists miss the autonomic tone parameter; so, it is essential to warn the anesthesiologist team to discuss before they use any autonomic drug. The vital signs (heart rate, oximetry, blood pressure, plethysmography, peripheral 
perfusion, capnography and respiratory gases) are strictly monitored. Skin adhesives of the 3D NavX ${ }^{\mathrm{TM}}$ or Velocity ${ }^{\mathrm{TM}}$ Electroanatomic Mapping System are applied and the esophageal echocardiography transductor is inserted. Brain function is monitored by spectral (BIS Aspect A-1000) keeping the consciousness level between 40 and 50 bi-spectral indexes. Conventional EP leads are placed and a routine EP study is carried out. Interatrial septum puncture is performed under transesophageal echocardiography guidance. Heparin $(100 \mathrm{IU} / \mathrm{kg})$ is used to keep the activated coagulation time around $300 \mathrm{~s}$. Mapping is performed with a spectrometer or by setting the EP conventional recorder filters.

\section{RF guided by spectral mapping or by endocardial potentials}

The patient must be in sinus rhythm and the right and left atrial endocardium are scanned with conventional irrigated catheter with the thermocontrolled RF generator. $\mathrm{RF}$ is applied in all places featured as AF Nest (fibrillar myocardium) (Fig. 6) aiming the elimination of the first neuron. Scanning may be guided by spectral mapping (Fig. 7) or by conventional recordings whit some filtering settings (Fig. 8).

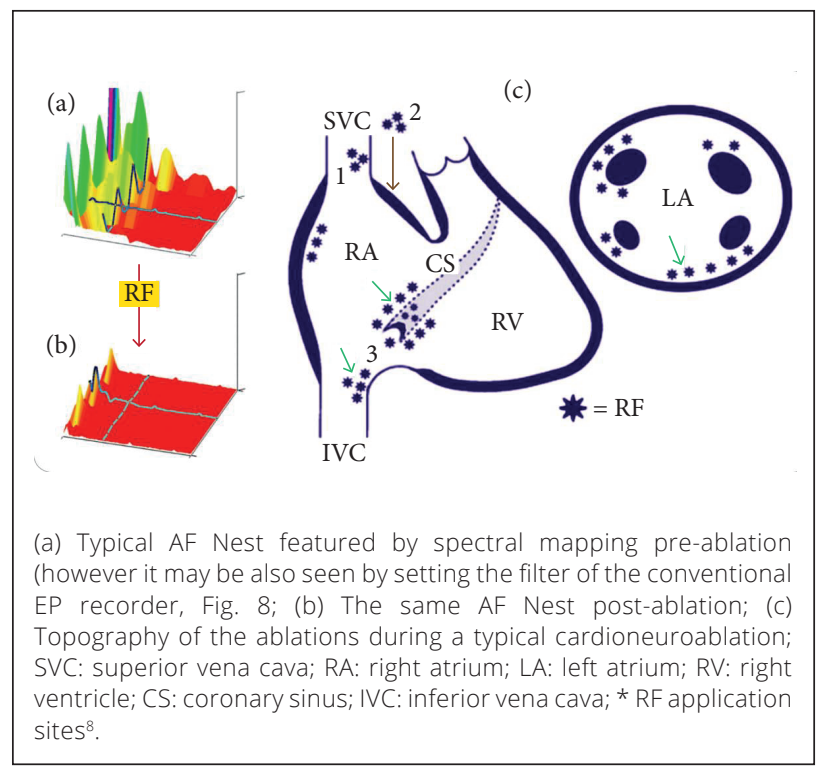

Figure 6. AF Nest main locations.

\section{RF guided by anatomical landmarks}

After ablation of all fibrillar scanned myocardium, endocardial anatomical ablation is also performed (at least $2 \mathrm{~min}$ in each place), in the areas related to the

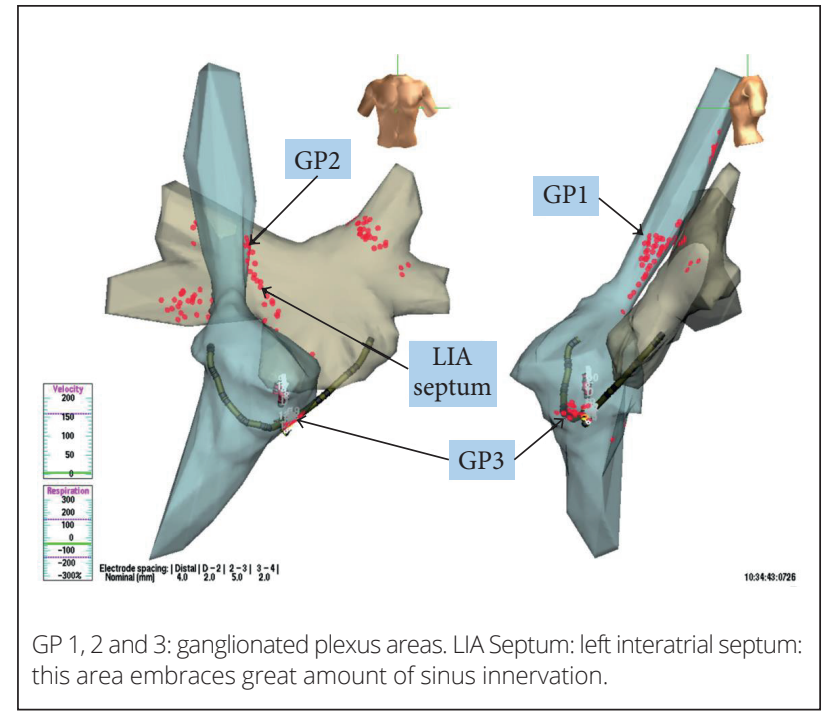

Figure 7. Typical electroanatomic mapping at the end of a regular CNA (not edited).

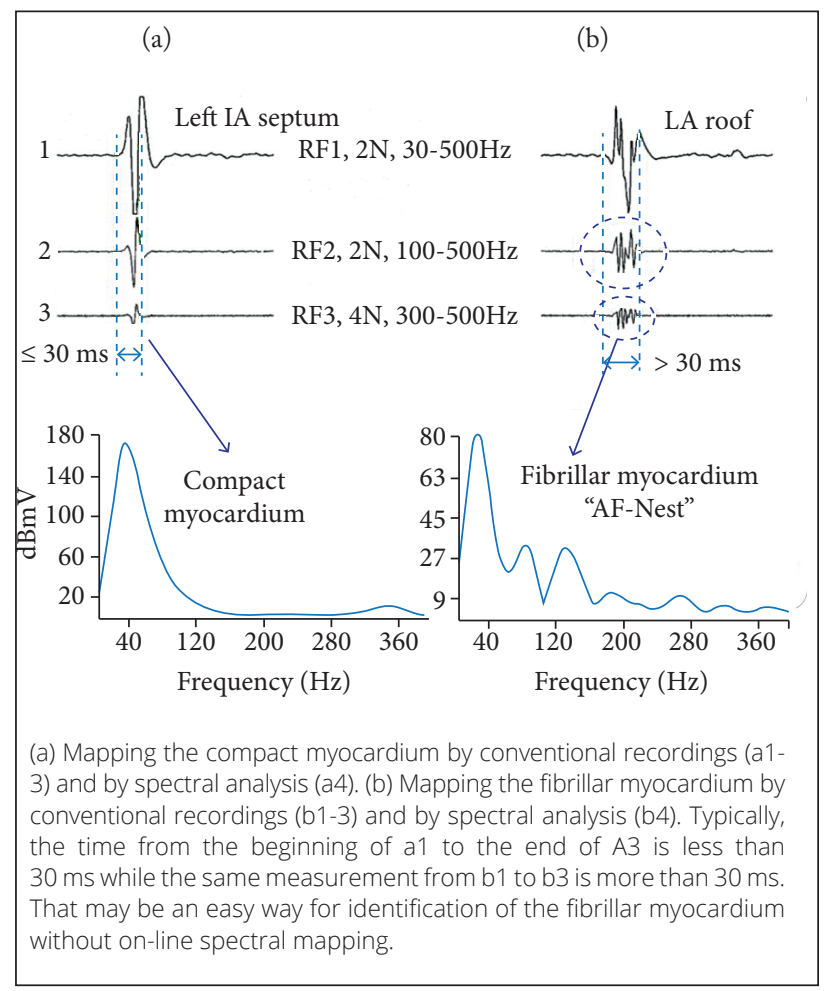

Figure 8. Conventional and Spectral recording

epicardial ganglionated plexuses $(\mathrm{GP})^{37}$. These areas typically present a high number of AF Nests and allow the elimination or depopulation of the second neuron. The RF in these areas should be extended for getting deep heating:

1. GP1: In the superior vena cava, medial and just above the vena cava atrial insertion (Figures $6 c$, 7 and 9-1); 
2. GP2: In the left interatrial septum, between the right pulmonary veins and the fossa ovalis (ablated through the LA) and from the fossa ovalis to the Waterston's groove (ablated through RA) (Figs. 6c, 7 and 9);

3. GP3: The roof of the coronary sinus (ablated through the LA) and by the inferior vena cava, medial and just under the tricuspid valve and the coronary sinus ostium (Figs. 6c, 7 and 9);

4. GPn: There are several other GPs even related to the pulmonary vein insertion ${ }^{34}$. Ancillary ablation of these sources may be obtained to a greater or lesser extent during pulmonary vein isolation (Fig. 7).

\section{Methodology for controlling and confirm the vagal denervation}

In this procedure, it is absolutely essential to have the demonstration of the vagal innervation effect, the stepwise control of denervation during the procedure and finally the confirmation of vagal denervation at the end of the proceedings, as an immediate endpoint for success criterion. For this purpose, we have developed the extracardiac vagal stimulation, which is a very easy neural stimulation to meet all these steps. The procedure begins with the advancement of an electrophysiology catheter within the right or left internal jugular veins up to the level of the jugular foramen (Figs. 10 and 11).

The vagal stimulator releases square wave pulses of 50 microseconds width, frequency of $30 \mathrm{~Hz}$ and amplitude from 10 to $70 \mathrm{~V}$, adjusted per patient weight (1 $\mathrm{V} / \mathrm{kg}$ up to $70 \mathrm{~V})$. An extremely short pulse duration with current limitation is employed for preventing tissue lesion. A timer function allows the application of pulse trains with predefined timing, usually between 5 to $10 \mathrm{~s}$.

A new vagal stimulation is repeated at the end of CNA and compared with the first one. The procedure is finished if confirmed total elimination of the vagal response (Fig. 12b). Additional vagal stimulations during the procedure are used to show the vagal denervation progress.

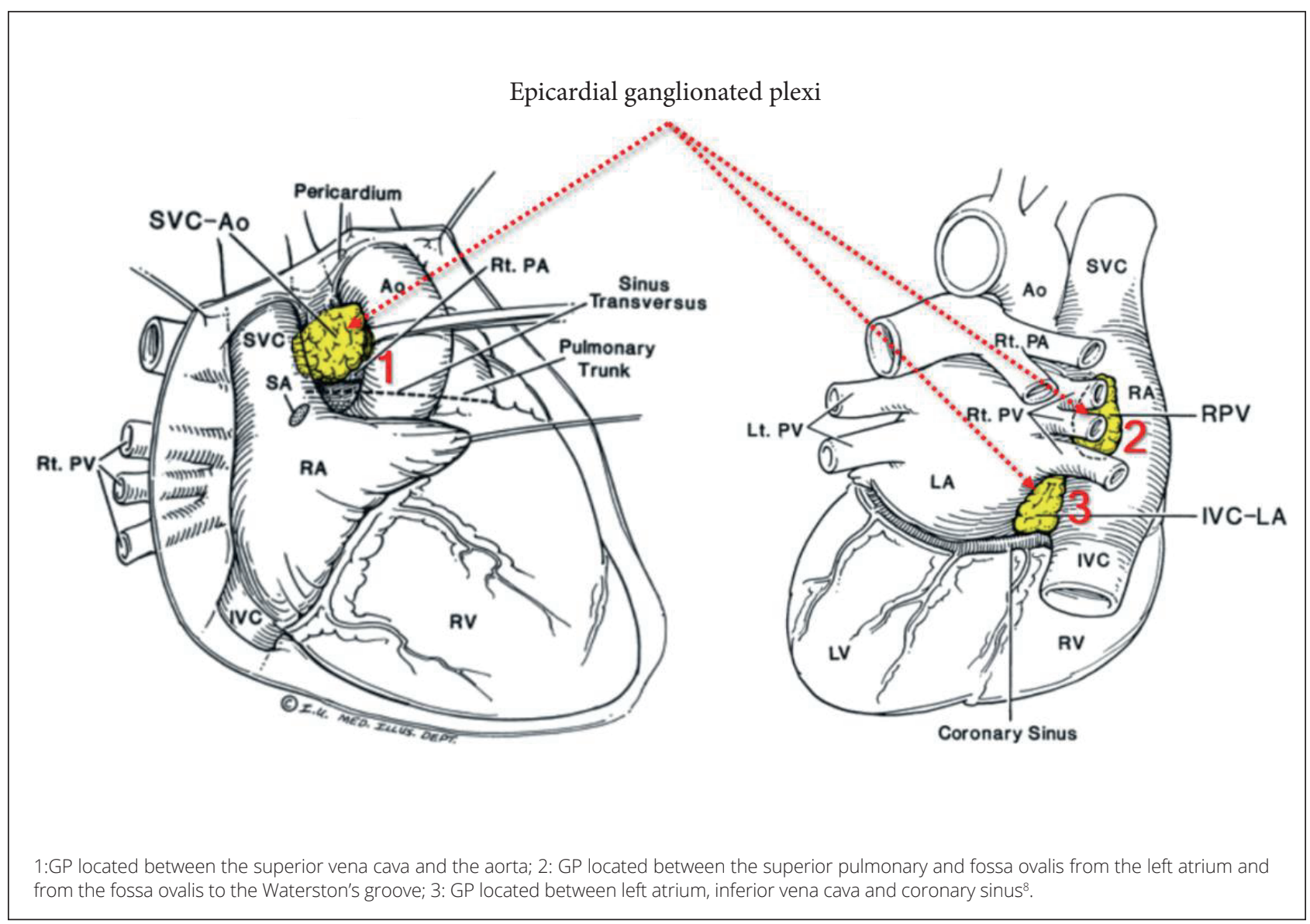

Figure 9. Topography of the main epicardial ganglionated plexus (GP) ${ }^{38}$. 


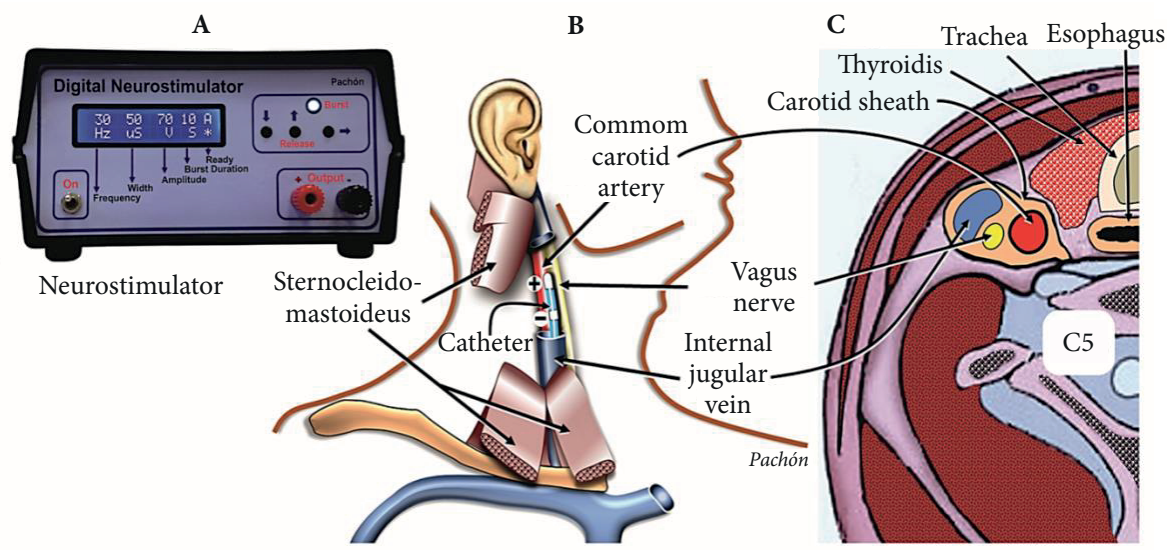

(a) Neurostimulator; (b) Scheme of the progression of the EP catheter inside the internal jugular vein up to jugular foramen; (c) Transverse section showing the close relation of the vagus with the internal jugular 33.

Figure 10. Methodology of vagal stimulation during cardioneuroablation.

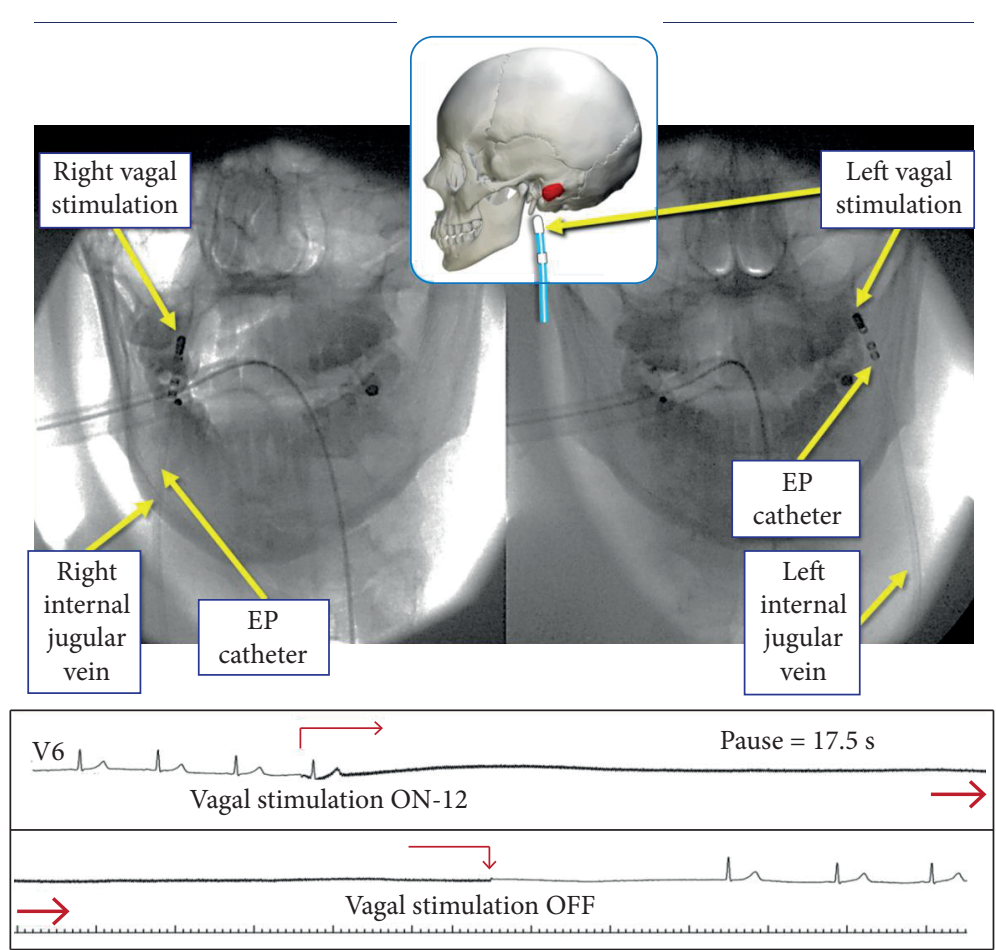

X-Ray showing the position of the EP catheter for vagal stimulation. A catheter is advanced within the internal jugular vein until the jugular foramen. Below, an example of the right vagal stimulation. There is a long asystole that lasts few seconds beyond the neurostimulation, depending on the sinus node recovery and the acetylcholine metabolism.

Figure 11. Site of vagal stimulation

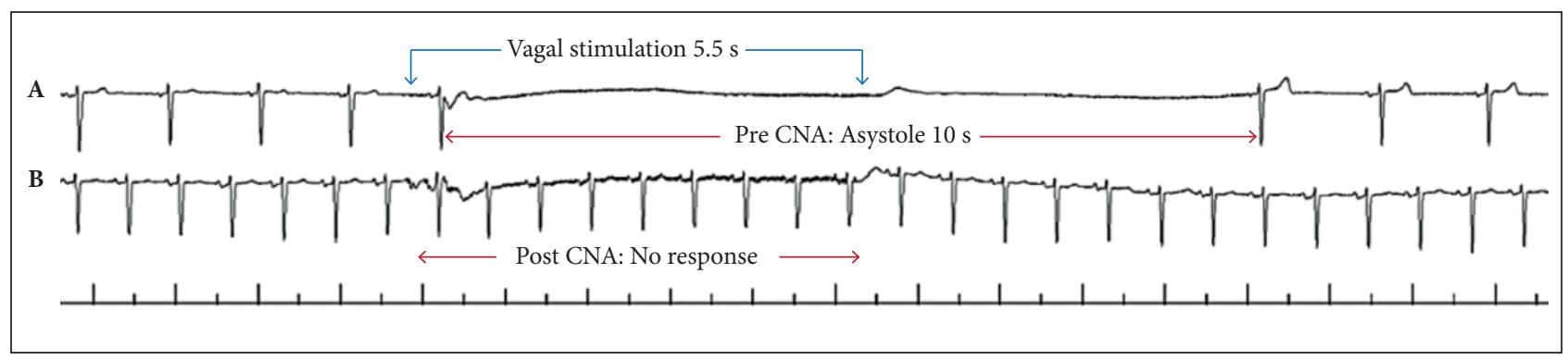

Figure 12. Vagal stimulation before (a) and at the end (b) of CNA demonstrating successful vagal denervation (complete abolition of vagal response). 


\section{Immediate cardioneuroablation endpoints}

Several endpoints must be considered to enhance the results of CNA, as shown in Table 2.

Table 2. Main immediate cardioneuroablation endpoints.

Ablation of the most AF-Nests in left atrium and right atrium

Anatomical ablation of main ganglionated plexuses areas

Sustained increase of the heart rate and Wenckebach's point

Complete suppression of the vagal response by vagal stimulation

Total abolition of the atropine response

\section{Esophageal protection during cardioneuroablation}

The wider the AF Nests ablation the greater and more lasting will be the vagal denervation. In addition to the regions of GPs, large vagal innervation enters the atria by the pulmonary veins insertion. Therefore, it is highly desirable to eliminate the AF-Nests related to these areas like the atrial fibrillation ablation. In this sense, special care for the protection of the esophagus is necessary. For this purpose, we developed a method, applied to all patients included in this study, which is the mechanical displacement of the esophagus by using the transesophageal echocardiographic transducer ${ }^{39}$. Usually, the displacement is enough to move the esophagus 4 to $8 \mathrm{~cm}$ in the opposite direction of the RF spot, expressively reducing the risk of esophageal heating and lesion (Fig. 13).

\section{RESULTS OF CARDIONEUROABLATION}

The immediate result at the end of CNA is the complete absence of vagal response indicating a successful vagal denervation (Fig. 12b). In fact, this is the main success criterion and if not achieved the ablation must be resumed and expanded until getting complete vagal response elimination.

The long-term outcome should be assessed primarily by the clinical follow-up, but it is required to be tried with the same assessment that demonstrated the most important cardioinhibitory response at the inclusion time, more often, the Tilt-test (Fig. 14). However, especially in cases of nonreflex functional bradyarrhythmias, the cardioinhibition may have been detected by stress-test or Holter recording. The Tilt-test is undoubtedly the most commonly used trial as an inclusion and control criterion. It is recommended to be repeated from 2 months post-CNA using the same protocol of the inclusion phase (Fig. 15).

In a long-term cohort study of 43 cardioinhibitory patients, with a FU of $45.1 \pm 22-11$ to 91.4 months $^{41}$, it was observed positive control Tilt-test only in 4 cases (9.3\%), with the same degree of cardioinhibition but, all of them, having a significant vasodepressor response, Table 3 .

These results show that the low number of patients presenting syncope after CNA appear to shift the vasovagal behavior from the severe cardioinhibition to a predominant less important vasodepressor response as the procedure significantly decreases the cardioinhibition response even in the long-term phase.
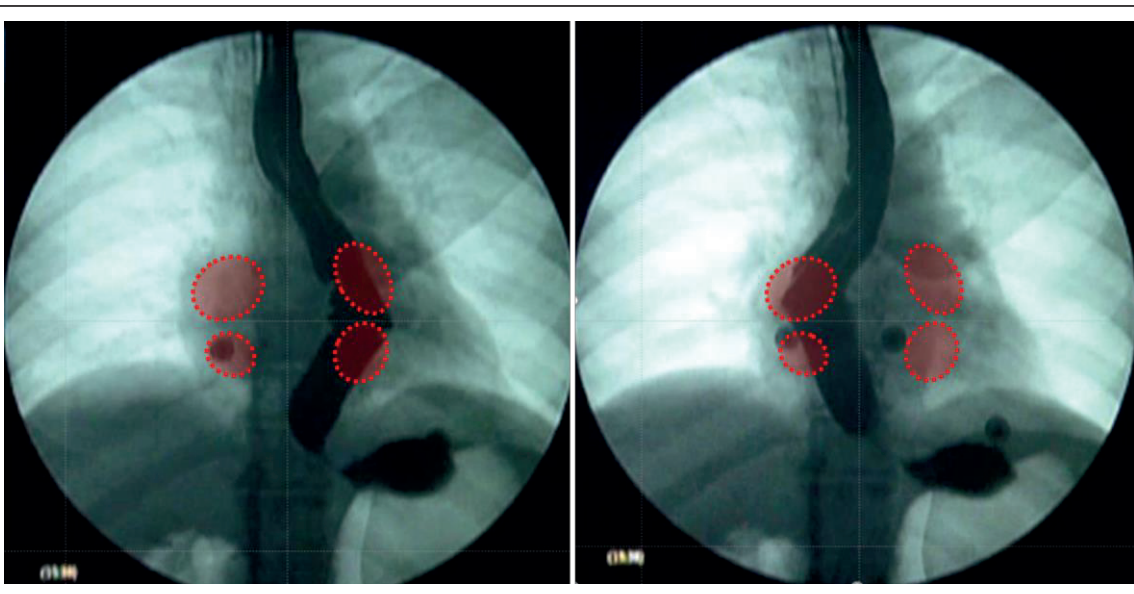

Figure 13. Contrast-enhanced radiography of the esophagus showing the displacement during RF ablation in the antrum of the pulmonary veins (red circles). The displacement extent is enough to allow a good protection of the esophagus in most patients ${ }^{40}$. 


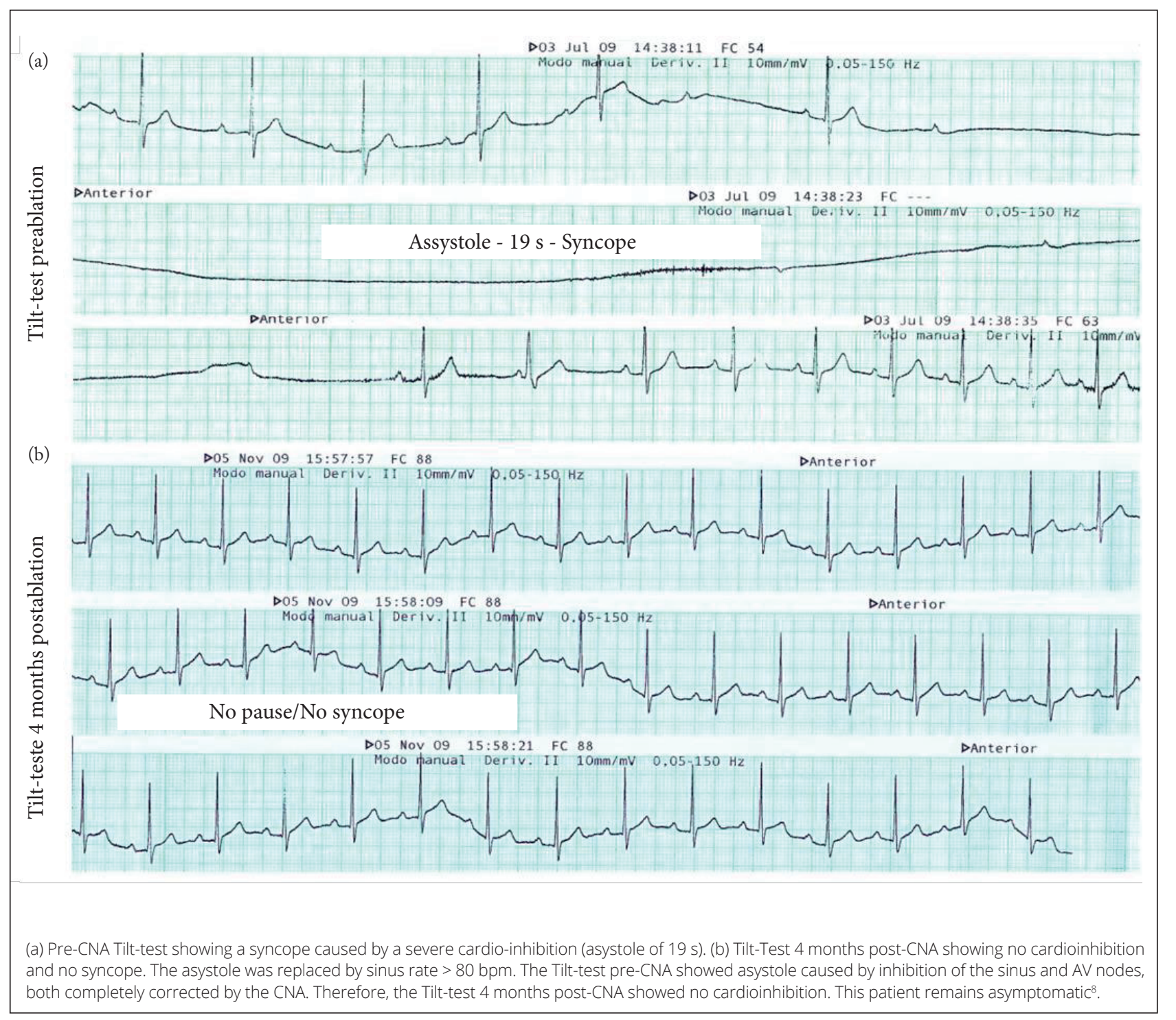

Figure 14. Tilt-Test for getting the long-term CNA outcome.

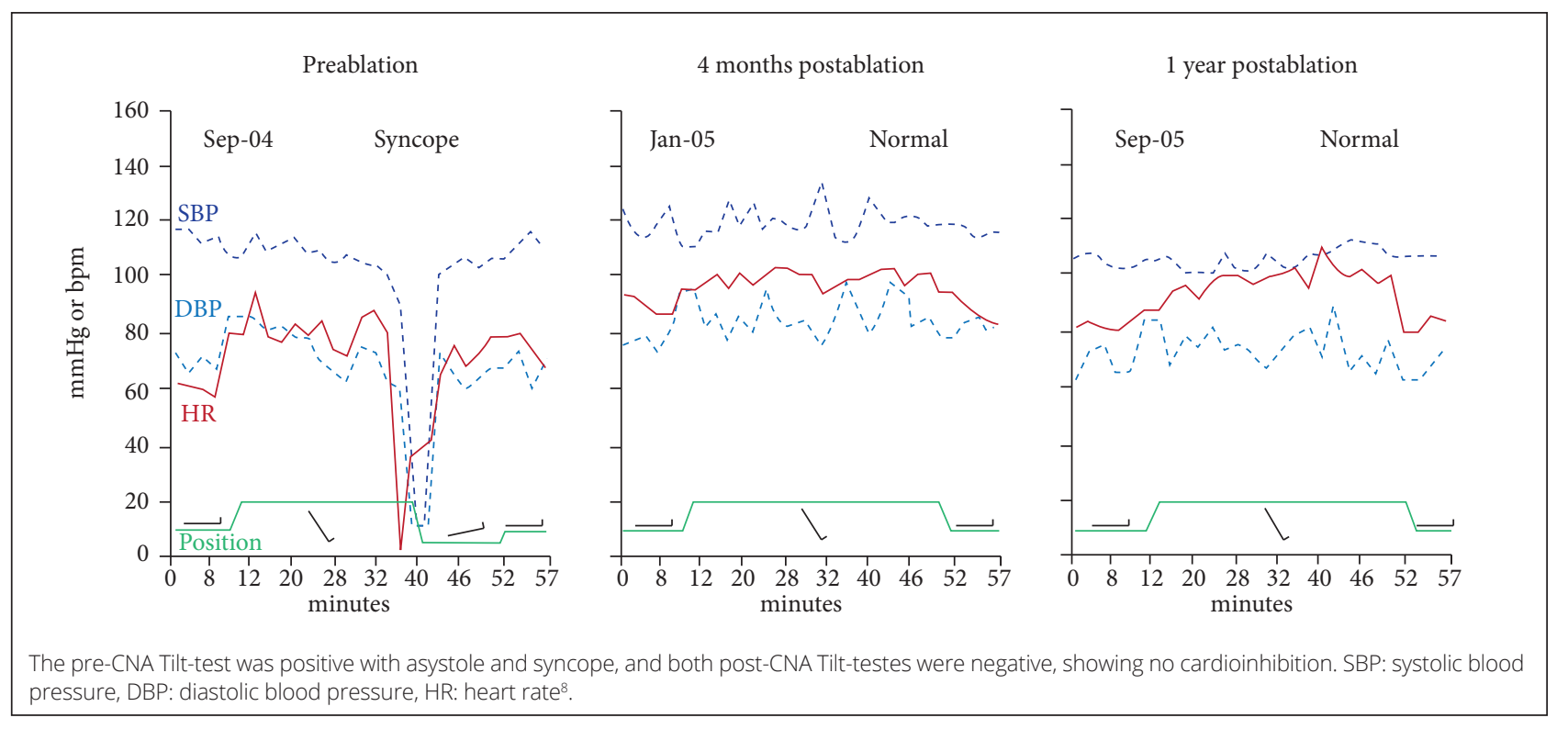

Figure 15. Tilt-test in the long follow-up of CNA. 
Table 3. Features of the cases with positive Tilt-test post-CNA in a cohort of 43 patients.

\begin{tabular}{|c|c|c|c|c|c|c|c|c|c|c|}
\hline \multirow[b]{2}{*}{ PIN } & \multirow[b]{2}{*}{ Age } & \multicolumn{4}{|c|}{ Pre-CNA Tilt-test } & \multicolumn{4}{|c|}{ Post-CNA Tilt-test } & \multirow[b]{2}{*}{ Outcome } \\
\hline & & TTD & Response & Cardioinhibition & $\begin{array}{l}\text { Pause } \\
\text { (sec) }\end{array}$ & TTD & Response & Cardioinhibition & FU & \\
\hline 7 & 48 & N & $\begin{array}{l}\text { Positive/ } \\
\text { Mixed }\end{array}$ & $\begin{array}{c}\text { Junctional } \\
\text { bradycardia }\end{array}$ & 3.7 & $N$ & $\begin{array}{l}\text { Positive/ } \\
\text { Mixed }\end{array}$ & $\begin{array}{l}\text { Sinus } \\
\text { bradycardia }\end{array}$ & 75 & Asymptomatic \\
\hline 17 & 17 & N & $\begin{array}{c}\text { Positive/ } \\
\text { Cardio- } \\
\text { inhibitory }\end{array}$ & Asystole & 12.0 & Y & $\begin{array}{l}\text { Positive/ } \\
\text { Mixed }\end{array}$ & $\begin{array}{c}\text { Sinus } \\
\text { bradycardia }\end{array}$ & 55 & $\begin{array}{c}\text { Dizziness } \\
\text { (menstrual colic) }\end{array}$ \\
\hline 26 & 14 & N & $\begin{array}{l}\text { Positive/ } \\
\text { Mixed }\end{array}$ & Sinus pause & 3.0 & $Y(42)$ & $\begin{array}{c}\text { Positive/ } \\
\text { Mixed }\end{array}$ & $\begin{array}{c}\text { Sinus } \\
\text { bradycardia }\end{array}$ & 43 & Asymptomatic \\
\hline 37 & 51 & Y & $\begin{array}{l}\text { Positive/ } \\
\text { Cardio- } \\
\text { inhibitory }\end{array}$ & Asystole & 6.0 & Y & $\begin{array}{l}\text { Positive/ } \\
\text { Mixed }\end{array}$ & $\begin{array}{c}\text { Junctional } \\
\text { bradycardia }\end{array}$ & 17 & Asymptomatic \\
\hline
\end{tabular}

PIN: patient identification number; TTD: Tilt-Test Drug; FU: Follow-up in months. significant reduction of the cardioinhibition compared to pre-CNA Tilt-test ${ }^{8}$

\section{Cardioneuroablation survival curves}

The therapeutic value of the $\mathrm{CNA}^{8}$ may be evaluated by comparing the results with the clinical treatment ${ }^{42}$ and with pacemaker implantation in the ISSUE- $3^{3}$ and SYNPACE ${ }^{37}$ studies. In Figure 16, even considering longer follow-up than other studies, by using CNA only 6 of 75 patients had indeterminate syncope (8\%) and the total of cases with

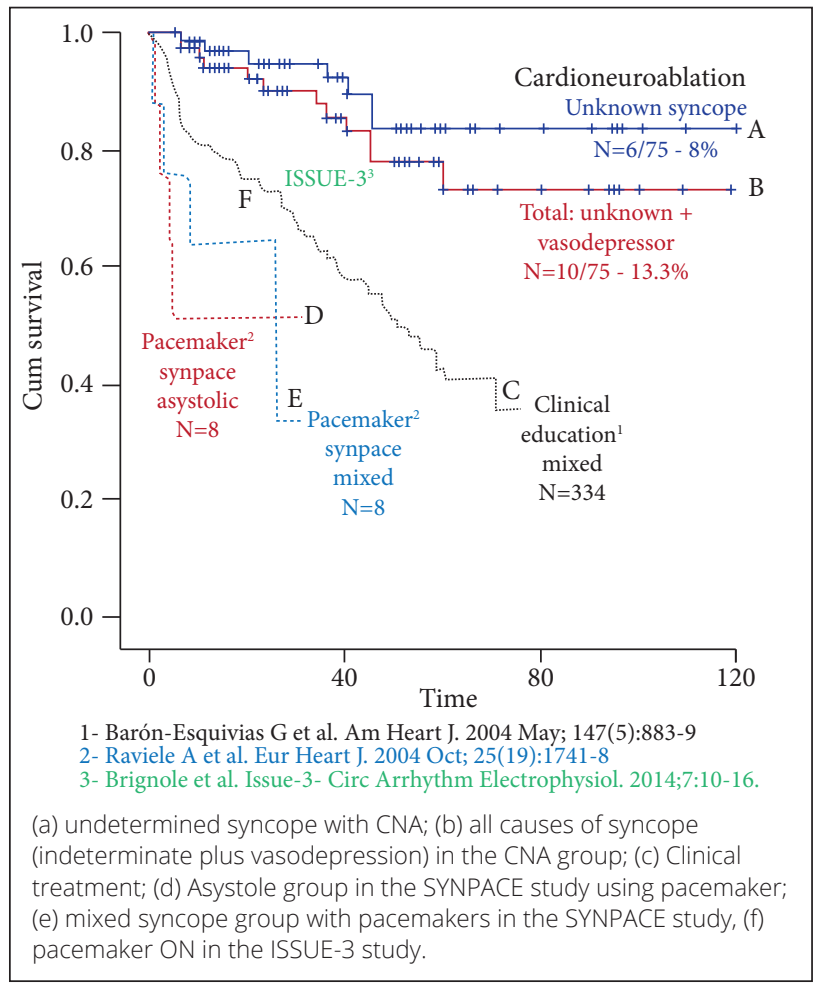

Figure 16. Survival curves free of syncope comparing the CNA with clinical treatment and with pacemaker implantation in the ISSUE-3 and SYNPACE studies. syncope indeterminate plus vasodepressor was 10 totaling $13.3 \%$ in a mean follow-up of $38 \pm 28$ months. However, if a shorter period of 24 months of follow-up is considered, as in the "International Study on Syncope of Uncertain Etiology 3 - ISSUE 3", the incidence of syncope was $9 \%$ with CNA, $25 \%$ with a pacemaker on in the ISSUE 3 study, $28 \%$ with clinical treatment, $35 \%$ in the mixed syncope group of the Synpace study and $48 \%$ in the asystolic group of the same study, both with pacemakers ON. Thus, it may be concluded that the CNA in patients with vasovagal syncope with important cardioinhibitory component presents better result when compared to clinical treatment and pacemaker implantation, providing the clinician with a new option to treat difficult cases.

\section{The CNA can bring undesirable consequences?}

Strictly follow-up of our patients over 14 years has shown no undesirable effect, even in the few cases in which the procedure was remade.

In the initial phase, there is a noteworthy change in the autonomic tone commonly observed as persistent sinus tachycardia. Because of this, it is customary to keep the patient with beta-blockers in the first 2 to 3 months. Clinically, there is a clear reduction or elimination of parasympathetic tone with a predominance of sympathetic one. However, gradually, there is a natural autonomic rebalancing with gradual reduction of the sympathetic drive bringing the 
heart rate to normal values. In this sense, there is a beneficial result of a long-time natural reduction of the sympathetic tone (Fig. 17a).

The patient shown in Fig. 15 had a basal heart rate of $62 \mathrm{ppm}$ in the pre-CNA tilt test, $85 \mathrm{ppm}$ in the 4 months control and $80 \mathrm{ppm}$ in tilt-test one-year postCNA. However, due to the readjustment of the autonomic nervous system, the patients usually remain asymptomatic with normal life. Due to this autonomic plasticity, the chronotropic response and the exercise capacity is also fully preserved as can be seen in the study of the postCNA exercise test, in which there was not observed additional chronotropic incompetence (Fig. 17b). One of the problems that must be questioned is if the reduction of RR variability may increase the cardiovascular risk. This effect was demonstrated after myocardial infarction and myocardial damage but there is no evidence that the primary $R R$ variability reduction caused by vagal denervation with fully preserved myocardial has some consequence in this regard.

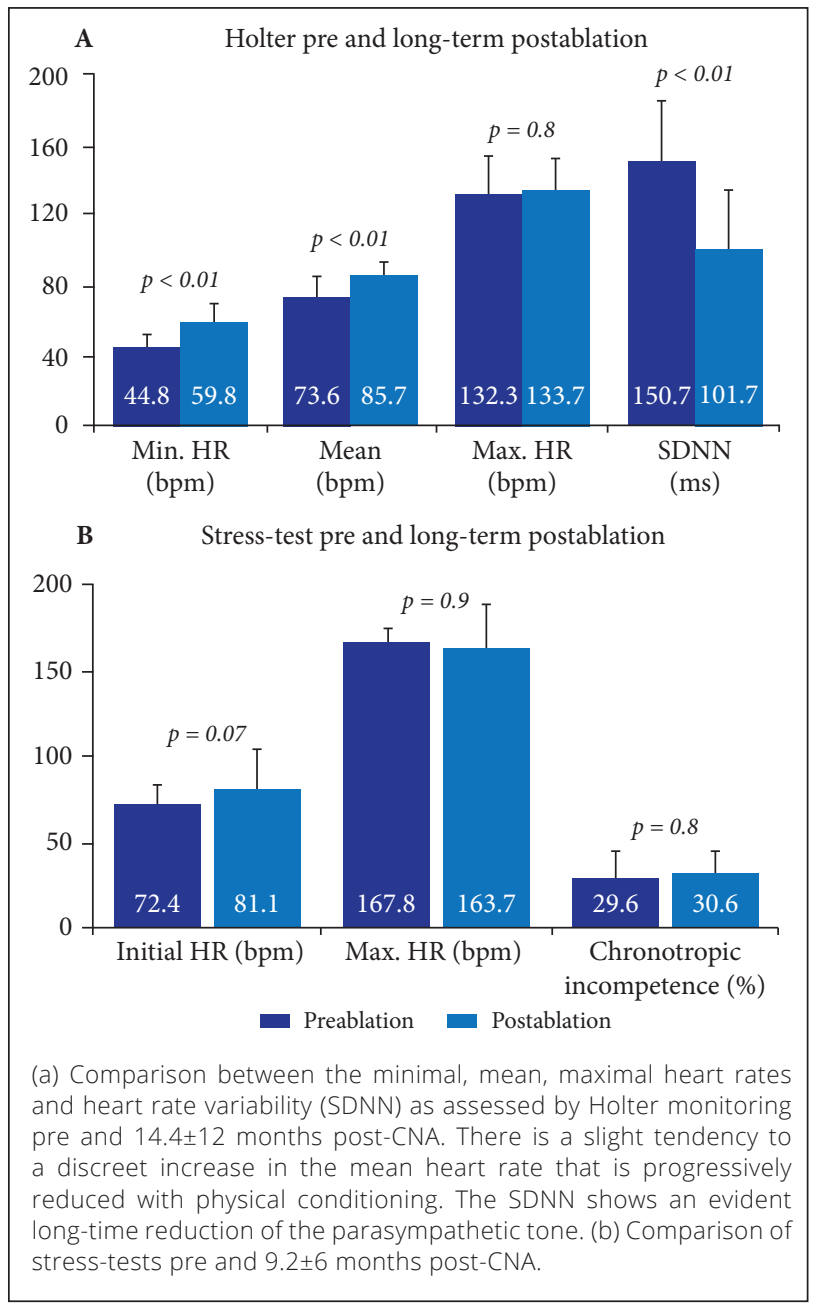

Figure 17. Holter pre- and post-RF.

\section{COMPLICATIONS}

With standard care, the CNA has been a very safe procedure. Its complication rate is equivalent to the ablation of paroxysmal AF in patients without heart disease. In a study of 44 CNA performed in 43 patients $^{8}$, there were no major complications being observed, only two small groin hematomas solved clinically by compression. One patient had an episode of typical atrial flutter during the hospital stay, reverted by intravenous amiodarone requiring no long-term therapy. Ten patients $(23.3 \%)$ were treated temporarily (1-3 months) with beta-blockers aiming the control of post-CNA mild sinus tachycardia. Physical conditioning was also indicated. No pacemaker implantation was needed. The patients were discharged after 2 days.

\section{LIMITATIONS}

The CNA is being reproduced by several investigators worldwide with similar good results. However, despite the positive results, randomized trials are required to further evaluate this therapeutic option. The application of RF anatomically guided over the GPs is not yet well defined and should be significantly improved in the future especially with the inclusion of imaging methods, such as magnetic resonance, and/or a ganglia marker, for example, a meta-iodobenzyl-guanidine scan, that accurately could indicate the position of the GPs that may exist in each case. Placebo effect is commonly observed in all treatment alternatives for neurally mediated reflex syncope, such as drugs, pacemaker implantation, education, and training. However, the significant and persistent autonomic changes observed after CNA, the abolishment of cardioinhibition in the control tilt-test and the undoubtedly long term better result, compared with other therapies, show that placebo effect plays an unimportant role in this therapy (Fig.15). One last limitation is that the CNA is an operator-dependent procedure with result highly related to the learning curve. Thus, controlled multicenter randomized trials should wait for the appropriate training of various services. 


\section{CONCLUSION}

Treatment of severe syncope cardioinhibitory by ablation without requiring pacemaker is very attractive, especially in young patients in whom the prosthesis is highly undesirable. In the studied cohort, a pacemaker was not necessary in any case. Despite no prevention of the vasodepression the CNA seems to cause enough long-term vagal reflex attenuation, eliminating the cardioinhibition, and keeping most patients asymptomatic. By using the current atrial fibrillation ablation technology, the procedure is safe, feasible, and reproducible. The indication is simple and essentially based on clinical findings, in the presence of severe cardioinhibition unresponsive to medical treatment, and on the normal response to atropine. Vagal stimulation to control the extent of the denervation in addition to confirming the immediate success seems to be decisive and indispensable. At last, as a rule for any new therapy, the results must be confirmed with experimental protocols and by randomized studies.

\section{AUTHORS' CONTRIBUTION}

Conceptualization, Mateos José CP; Methodology, Mateos José CP and Mateos EIP; Writing - First version, Mateos José CP; Writing - Review \& Editing, Mateos José CP, Mateos EIP, Pachón CTC and Lobo TJ; Acquisition, Mateos José CP; Mateos EIP, Pachón CTC, Lobo TJ, Higuti C, Peña TGS, Mateos Juan CP, Acosta JCZ, Ortencio F and Amarante R; Resources, Mateos José CP and Mateos EIP; Supervision, Mateos José CP.

\section{REFERENCES}

1. Sheldon RS, Grubb BP, Olshansky B, Shen WK, Calkins H, Brignole M, et al. 2015 Heart rhythm society expert consensus statement on the diagnosis and treatment of postural tachycardia syndrome, inappropriate sinus tachycardia, and vasovagal syncope. Heart Rhythm. 2015;12(6):e41-63. https://doi.org/10.1016/j. hrthm.2015.03.029

2. Moya A, Sutton R, Ammirati F, Blanc J-J, Brignole M, Dahm $J B$, et al. Guidelines for the diagnosis and management of syncope (version 2009): The Task Force for the Diagnosis and Management of Syncope of the European Society of Cardiology (ESC). Eur Heart J. 2009;30(21):2631-71. https://doi.org/10.1093/eurheartj/ehp298

3. Brignole M, Menozzi C, Moya A, Andresen D, Blanc J-J, Krahn $A D$, et al. Pacemaker therapy in patients with neurally mediated syncope and documented asystole. Third International Study on Syncope of Uncertain Etiology (ISSUE 3). A randomized trial. Circulation. 2012;125(21):2566-71. https://doi.org/10.1161/CIRCULATIONAHA.111.082313

4. Epstein AE, DiMarco JP, Ellenbogen KA, Estes NAM, Freedman RA, Gettes LS, et a. ACC/AHA/HRS 2008 guidelines for device-based therapy of cardiac rhythm abnormalities: Executive summary - A report of the American College of Cardiology/American Heart Association Task Force on Practice Guidelines (Writing Committee to Revise the ACC/AHA/NASPE 2002 Guideline Update for Implantation of Cardiac Pacemakers and Antiarrhythmia Devices). Circulation. 2008;117:2820-40. https://doi.org/10.1161/CIRCUALTIONAHA.108.189741

5. Pachon MJC, Pachon MEl, Pachon MJC, Lobo TJ, Pachon $M Z$, Vargas RN, et al. "Cardioneuroablation" - new treatment for neurocardiogenic syncope, functional AV block and sinus dysfunction using catheter RF-ablation. Europace. 2005;7(1):1-13. https://doi.org/10.1016/j. eupc.2004.10.003

6. Morillo CA, Eckberg DL, Ellenbogen KA, Beightol LA, Hoag JB, Tahvanainen KU, et al. Vagal and sympathetic mechanisms in patients with orthostatic vasovagal syncope. Circulation. 1997;96(8):2509-13. https://doi. org/10.1161/01.cir.96.8.2509

7. Armour JA. Potential clinical relevance of the 'little brain' on the mammalian heart. Exp Physiol. 2008;93(2):16576. https://doi.org/10.1113/expphysiol.2007.041178

8. Pachón MJC, Pachón MEI, Pachón MZC, Lobo TJ, Pachón MJC, Santillana PTG. Catheter ablation of severe neurally meditated reflex (neurocardiogenic or vasovagal) syncope: cardioneuroablation long-term results. Europace. 2011;13(9):1231-42. https://doi.org/10.1093/ europace/eur163

9. Taylor EW, Jordan D, Coote JH. Central control of the cardiovascular and respiratory systems and their interactions in vertebrates. Physiol Rev. 1999;79(3):855916. https://doi.org/10.1152/physrev.1999.79.3.855

10. Santini M, Ammirati F, Colivicchi F, Gentilucci G, Guido $\checkmark$. The effect of atropine in vasovagal syncope induced by head-up tilt testing. Eur Heart J. 1999;20(23):1745-51. https://doi.org/10.1053/euhj.1999.1697

11. Gallego JC, Cubero JS, Pulpón LA, Rodríguez MA, Salas C, Ortiz-Berrocal J. Angina pectoris in the heart transplant recipient: evidence of reinnervation. Rev Esp Cardiol. 
2001;54(6):799-802. https://doi.org/10.1016/s03008932(01)76396-8

12. Murphy DA, Thompson GW, Ardell JL, McCraty R, Stevenson RS, Sangalang VE, et al. The heart reinnervates after transplantation. Ann Thorac Surg. 2000;69(6):176981. https://doi.org/10.1016/s0003-4975(00)01240-6

13. Coyer BH, Pryor R, Kirsch WM, Blount Júnior SG. Left stellectomy in the long QT syndrome. Chest. 1978;74(5):584-6. https://doi.org/10.1378/ chest.74.5.584

14. Pappone C, Santinelli V, Manguso F, Vicedomini G, Gugliotta F, Augello G, et al. Pulmonary vein denervation enhances long-term benefit after circumferential ablation for paroxysmal atrial fibrillation. Circulation. 2004;109(3):327-34. https://doi.org/10.1161/01. CIR.0000112641.16340.C7

15. Po SS, Nakagawa $H$, Jackman WM. Localization of left atrial ganglionated plexi in patients with atrial fibrillation. J Cardiovasc Electrophysiol. 2009;20(10):1186-9. https:// doi.org/10.1111/j.1540-8167.2009.01515.x

16. Driessen AH, Berger WR, Krul SP, van den Berg NW, Neefs J, Piersma FR, et al. Ganglion plexus ablation in advanced atrial fibrillation: The AFACT study. J Am Coll Cardiol. 2016;68(11):1155-65. https://doi.org/10.1016/j. jacc.2016.06.036

17. Aksu T, Baysal E, Guler TE, Yalin K. Selective right atrial cardioneuroablation in functional atrioventricular block. Europace. 2016;19(2):333. https://doi.org/10.1093/ europace/euv413

18. Aksu T, Golcuk E, Yalin K, Guler TE, Erden I. Simplified cardioneuroablation in the treatment of reflex syncope, functional AV block, and sinus node dysfunction. Pacing Clin Electrophysiol. 2016;39(1):42-53. https://doi. org/10.1111/pace.12756

19. Rivarola E, Hardy C, Sosa E, Hachul D, Furlan V, Raimundi $F$, et al. Selective atrial vagal denervation guided by spectral mapping to treat advanced atrioventricular block. Europace. 2016;18(3):445-9. https://doi. org/10.1093/europace/euv142

20. Klank-Szafran M, Stec S, Sledz J, Janion M. Radiofrequency ablation and cardioneuroablation for AVNRT and atrioventricular block. Kardiol Pol. 2010;68(6):720-4.

21. Yao $Y$, Shi R, Wong $T$, Zheng $L$, Chen $W$, Yang $L$, et al. Endocardial autonomic denervation of the left atrium to treat vasovagal syncope: an early experience in humans. Circ Arrhythm Electrophysiol. 2012;5(2):279-86. https:// doi.org/10.1161/CIRCEP.111.966465

22. Liang Z, Jiayou Z, Zonggui W, Dening L. Selective atrial vagal denervation guided by evoked vagal reflex to treat refractory vasovagal syncope. Pacing Clin Electrophysiol. 2012;35(7):e214-8. https://doi.org/10.1111/j.15408159.2011.03320.x

23. Scanavacca M, Hachul D, Pisani C, Sosa E. Selective vagal denervation of the sinus and atrioventricular nodes, guided by vagal reflexes induced by high frequency stimulation, to treat refractory neurally mediated syncope. J Cardiovasc Electrophysiol. 2009;20(5):558-63. https://doi.org/10.1111/j.1540-8167.2008.01385.x

24. Stavrakis S, Scherlag BJ, Po SS. Autonomic modulation: an emerging paradigm for the treatment of cardiovascular diseases. Circ Arrhythm Electrophysiol. 2012;5(2):247-8. https://doi.org/10.1161/CIRCEP.112.972307

25. Fukunaga M, Wichterle $\mathrm{D}$, Peichl $\mathrm{P}$, Aldhoon B, Cihák R, Kautzner J. Differential effect of ganglionic plexi ablation in a patient with neutrally mediated syncope and intermittent atrioventricular block. Europace. 2016;19(1):119-26. https://doi.org/10.1093/europace/ euw100

26. Pachón MJC, Pachón MEI, Pachón MJC, Lobo TJ, Pachón $M Z$, Vargas RNA, et al. A new treatment for atrial fibrillation based on spectral analysis to guide the catheter RF-ablation. Europace. 2004;6(6):590-601. https://doi.org/10.1016/j.eupc.2004.08.005

27. Chang HY, Lo LW, Lin YJ, Lee SH, Chiou CW, Chen SA. Relationship between intrinsic cardiac autonomic ganglionated plexi and the atrial fibrillation nest. Circ J. 2014;78(4):922-8. https://doi.org/10.1253/circj.cj-131053

28. Singhal R, Lo LW, Lin YJ, Chang SL, Hu YF, Chao TF, et al. Intrinsic cardiac autonomic ganglionated plexi within epicardial fats modulate the atrial substrate remodeling: experiences with atrial fibrillation patients receiving catheter ablation. Acta Cardiol Sin. 2016;32(2):174-84. https://doi.org/10.6515/acs20150427a

29. Oh S, Kong HJ, Choi EK, Kim HC, Choi YS. Complex fractionated electrograms and AF nests in vagally mediated atrial fibrillation. Pacing Clin Electrophysiol. 2010;33(12):1497-503. https://doi.org/10.1111/j.15408159.2010.02834.x

30. Pachon M JC, Arruda M. Spectral mapping identifies critical atrial myocardial sites prone to "electrical resonance": could it be the missing puzzle piece in the physiopathology of AF maintenance? J Cardiovasc Electrophysiol. 2012;23(11):1163-4. https://doi. org/10.1111/j.1540-8167.2012.02444.x

31. Mateos JCP, Mateos EIP, Lobo TJ, Pachón MZC, Mateos JCP, Pachón DQ, et al. Radiofrequency catheter ablation of atrial fibrillation guided by spectral mapping of atrial fibrillation nests in sinus rhythm. Arq Bras Cardiol. 2007;89(3):124-34/140-50. https://doi.org/10.1590/ s0066-782x2007001500001

32. Arruda $M$, Natale A. Ablation of permanent AF: adjunctive strategies to pulmonary veins isolation: targeting AF NEST in sinus rhythm and CFAE in AF. J Interv Card Electrophysiol. 2008;23(1):51-7. https://doi. org/10.1007/s10840-008-9252-z

33. Pachon MJC, Pachon MEI, Santillana PTG, Lobo TJ, Pachon CTC, Pachon MJC, et al. Simplified method for vagal effect evaluation in cardiac ablation and electrophysiological 
procedures. JACC Clin Electrophysiol. 2015;1(5):451-60. https://doi.org/10.1016/j.jacep.2015.06.008

34. Pauza DH, Skripka V, Pauziene N, Stropus R. Anatomical study of the neural ganglionated plexus in the canine right atrium: implications for selective denervation and electrophysiology of the sinoatrial node in dog. Anat Rec. 1999;255(3):271-94. https://doi.org/10.1002/ (SICI)1097-0185(19990701)255:3\%3C271::AID AR4\%3E3.0.CO;2-2

35. Pachon MJC, Pachon MEI, Lobo TJ, Pachon MJC, Pachon MZ, Vargas RN, et al. Syncopal high-degree AV block treated with catheter RF ablation without pacemaker implantation. Pacing Clin Electrophysiol. 2006;29(3):31822. https://doi.org/10.1111/j.1540-8159.2006.00340.x

36. Pauza DH, Skripka V, Pauziene N, Stropus R. Morphology, distribution, and variability of the epicardiac neural ganglionated subplexuses in the human heart. Anat Rec. 2000;259(4):353-82. https://doi. org/10.1002/1097-0185(20000801)259:4\%3C353::AIDAR10\%3E3.0.CO;2-R

37. Chiou C-W, Eble JN, Zipes DP. Efferent Vagal Innervation of the Canine Atria and Sinus and Atrioventricular Nodes - The Third Fat Pad. Circulation. 1997;95(11):2573-84. https://doi.org/10.1161/01.cir.95.11.2573
38. Lellouche N, Buch E, Celigoj A, Siegerman C, Cesario $D$, Diego C. et al. Functional characterization of atrial electrograms in sinus rhythm delineates sites of parasympathetic innervation in patients with paroxysmal atrial fibrillation. J Am Coll Cardiol. 2007;50(14):1324-31. https://doi.org/10.1016/j.jacc.2007.03.069

39. Hachul D. Does non-pharmacological treatment affect outcomes in dysautonomic syndromes? Cardiol J. 2014;21(6):611-5. https://doi.org/10.5603/ CJ.2014.0093

40. Mateos JCP, Mateos EIP, Peña TG, Lobo TJ, Mateos JCP, Vargas RN, et al. Simplified method for esophagus protection during radiofrequency catheter ablation of atrial fibrillation--prospective study of 704 cases. Rev Bras Cir Cardiovasc. 2015;30(2):139-47. https://doi. org/10.5935/1678-9741.20150009

41. Olshansky B, Sullivan RM. Syncope in Patients with Organic Heart Disease. Cardiol Clin. 2015;33(3):449-63. https://doi.org/10.1016/j.ccl.2015.04.013

42. Pauza DH, Skripka V, Pauziene N. Morphology of the intrinsic cardiac nervous system in the dog: a whole-mount study employing histochemical staining with acetylcholinesterase. Cells Tissues Organs. 2002;172(4):297-320. https://doi. org/10.1159/000067198 